\title{
PENYULUHAN TENTANG CUCI TANGAN PAKAI SABUN (CTPS) UNTUK MENCEGAH PEYEBARAN CORONAVIRUS (COV) DI WILAYAH KERJA PUSKESMAS KARANG PULE
}

\author{
Cahaya Indah Lestari ${ }^{1)}$, Catur Esty Pamungkas ${ }^{2)}$, Siti Mardiyah WD ${ }^{2)}$ \\ Baiq Masdariah 2)
}

\begin{abstract}
1)Program Studi S1 Kebidanan, Fakultas IImu Kesehatan, Universitas Muhammadiyah Mataram, Mataram, NTB, Indonesia
2)Program Studi D3 Kebidanan, Fakultas IImu Kesehatan, Universitas Muhammadiyah Mataram, , Mataram, NTB, Indonesia

Corresponding author : Cahaya Indah Lestari

E-mail : (cahayaisnaini2011@gmail.com)
\end{abstract}

Diterima 14 Oktober 2020, Direvisi 26 Oktober 2020, Disetujui 27 Oktober 2020

\begin{abstract}
ABSTRAK
Secara global dilaporkan 51.857 kasus konfimasi di 25 negara dengan 1.669 kematian (CFR 3,2\%). Jumlah pasien positif Covid-19 di Provinsi NTB sampai tanggal (30/6/2020) sebanyak 1.245 orang, dengan perincian 825 orang sudah sembuh, 65 meninggal dunia, serta 355 orang masih positif dan dalam keadaan baik. Sedangkan jumlah pasien positif Covid-19 di Kota Mataram sebanyak 531 orang, dengan perincian 189 sedang dirawat, 310 orang sudah sembuh, 32 meninggal dunia. Tujuan pengabdian ini untuk mencegah penyebaran coronavirus (COV) di wilayah kerja Puskesmas Karang Pule Kegiatan penyuluhan ini menggunakan video cara Cuci Tangan Pakai Sabun (CTPS) Kemenkes dimana peserta pengabdian yang hadir berjumlah 20 orang. Kegiatan ini dilakukan dalam tiga tahap. Tahap pertama yakni pembagian kuesioner dan pemaparan, tahap kedua yakni Praktek Cuci Tagan Pakai Sabun dan tahap ketiga yakni tanya jawab serta pembagian kuesioner post test. Kegiatan pengabdian ini disambut sangat antusias, ibu melontarkan beberapa pertanyaan terkait Cuci Tangai Pakai Sabun dan pembuatan cairan disinfektan Sebagian besar ibu paham dengan penyuluhan yang diberikan. Penyuluhan ini dapat meningkatkan pengetahuan ibu dengan kategori pengetahuan baik sebesar 90 \% (18 Orang) tentang Cuci Tangan Pakai Sabun (CTPS) untuk pencegahan coronavirus .
\end{abstract}

Kata kunci: Penyuluhan; Cuci Tangan Pakai Sabun; Pencegahan Coronavirus.

\begin{abstract}
Globally, 51,857 confirmed cases were reported in 25 countries with 1,669 deaths (CFR $3.2 \%$ ). The number of Covid-19 positive patients in NTB Province as of (6/30/2020) was 1,245 people, with details of 825 people recovered, 65 dead, and 355 people still positive and in good condition. While the number of positive patients Covid-19 in the city of Mataram was 531 people, with the details of 189 being treated, 310 people were cured, 32 died. The purpose of this service is to prevent the spread of coronavirus (COV) in the working area of Karang Pule Health Center. This counseling activity uses a video on how to wash hands with soap (CPTS) from the Ministry of Health where there are 20 community service attendees. This activity is carried out in three stages. The first stage is the distribution of questionnaires and exposure, the second stage is the Practice of Washing with Soap and the third stage is the question and answer session and the distribution of post test questionnaires. This service was welcomed with great enthusiasm, the mother asked a number of questions related to washing Tangai with soap Most of the mothers understood the counseling given. This counseling can increase the knowledge of mothers with good knowledge categories by $90 \%$ (18 people) about Handwashing with Soap (CTPS) for the prevention of coronavirus.
\end{abstract}

Keywords: Counseling; hand washing behavior with soap; Coronavirus Prevention.

\section{PENDAHULUAN}

Coronavirus (CoV) adalah keluarga besar virus yang menyebabkan penyakit mulai dari gejala ringan sampai berat. Ada setidaknya dua jenis coronavirus yang diketahui menyebabkan penyakit yang dapat menimbulkan gejala berat seperti Middle East Respiratory Syndrome (MERS) dan Severe Acute Respiratory
Syndrome (SARS). Coronavirus Disease (COVID-19) adalah virus jenis baru yang belum pernah diidentifikasi sebelumnya pada manusia. Virus corona adalah zoonosis (ditularkan antara hewan dan manusia). Penelitian menyebutkan bahwa SARS ditransmisikan dari kucing luwak (civet cats) ke manusia dan MERS dari unta ke manusia. Beberapa coronavirus yang dikenal 
beredar pada hewan namun belum terbukti menginfeksi manusia. Manifestasi klinis biasanya muncul dalam 2 hari hingga 14 hari setelah paparan. Tanda dan gejala umum infeksi coronavirus antara lain gejala gangguan pernapasan akut seperti demam, batuk dan sesak napas.(Kementrian Kesehatan, 2020)

WHO melaporkan bahwa penularan dari manusia ke manusia terbatas (pada kontak erat dan petugas kesehatan) telah dikonfirmasi di China maupun negara lain. Berdasarkan kejadian MERS dan SARS sebelumnya, penularan manusia ke manusia terjadi melalui droplet, kontak dan benda yang terkontaminasi, maka penularan COVID-19 diperkirakan sama. Rekomendasi standar untuk mencegah penyebaran infeksi adalah melalui cuci tangan secara teratur, menerapkan etika batuk dan bersin, menghindari kontak secara langsung dengan ternak dan hewan liar serta menghindari kontak dekat dengan siapa pun yang menunjukkan gejala penyakit pernapasan seperti batuk dan bersin (Duerink et al., 2006). Secara global dilaporkan 51.857 kasus konfimasi di 25 negara dengan 1.669 kematian (CFR 3,2\%). Jumlah pasien positif Covid-19 di Provinsi NTB sampai tanggal (30/6/2020) sebanyak 1.245 orang, dengan perincian 825 orang sudah sembuh, 65 meninggal dunia, serta 355 orang masih positif dan dalam keadaan baik. Sedangkan jumlah pasien positif Covid-19 di Kota Mataram sebanyak 531 orang, dengan perincian 189 sedang dirawat, 310 orang sudah sembuh, 32 meninggal dunia.

Berbagai macam jenis virus, bakteri dan jamur menempel pada tangan setiap harinya melalui kontak fisik. Untuk mencegah penyebaran virus, bakteri dan jamur, salah satu cara yang paling tepat adalah mencuci tangan dengan sabun dan air bersih yang mengalir. Jika air bersih tidak tersedia, dapat menggunakan sabun dan air yang tersedia. Namun dapat juga digunakan pembersih tangan berbasis alkohol untuk membersihkan tangan (Wijaya, 2013)

Membersihkan tangan dengan bahan antiseptik mulai dikenal sejak awal abad 19. Perkembangan masyarakat modern yang menuntut manusia untuk bergerak cepat dan menggunakan waktu seefisien mungkin. Tuntutan zaman yang demikian mengharuskan manusia untuk menjaga kesehatannya agar terhindar dari penyakit yang dapat menghambat gerak dan mengurangi efisiensi waktunya (Rajaraman et al., 2014). Mencuci tangan dengan sabun merupakan upaya pencegahan sebagai perlindungan tubuh dari berbagai penyakit yang sifatnya menular. Mencuci tangan dengan sabun dapat dilakukan ketika selesai BAB dan BAK, sebelum makanan disiapkan, sebelum dan sesudah mengkonsumsi makanan, sehabis bermain pada anak, setelah batuk atau bersin serta setelah membuang ingus (Sugiarto et al., 2019).Pemakaian antiseptik tangan dalam bentuk sediaan gel di kalangan masyarakat menengah ke atas sudah menjadi suatu gaya hidup. Beberapa sediaan hand sanitizer dapat dijumpai di pasaran dan biasanya banyak yang mengandung alkohol. Cara pemakaiannya dengan diteteskan pada telapak tangan, kemudian diratakan pada permukaan tangan (Dewi et al., 2016).

Salah satu upaya pencegahan dasar virus corona atau Covid-19 adalah dengan rajin mencuci tangan secara detail dan menyeluruh. Hal ini karena virus corona menular lewat droplet atau cairan tubuh yang keluar saat batuk atau bersin. Selain tertular karena menghirup droplet ketika berada dekat dengan orang yang terinfeksi, Anda juga bisa tertular virus corona lewat tangan sebagai media penularan. Sebagai contoh adalah ketika Anda berjabat tangan dengan orang menutupi batuk dengan tangannya, atau ketika Anda menyentuh obyek yang terpapar virus corona. Itulah sebabnya, sangat penting untuk mencuci tangan menggunakan sabun dan air mengalir secara detail dan menyeluruh. Para ahli merekomendasikan cuci tangan untuk dilakukan setidaknya 20 detik. Sebab, sabun butuh waktu untuk mengikat molekul air dan minyak secara bersamaan, dan mengangkat kuman-kuman pada tangan Anda untuk dibuang bersama aliran air (Tim Kerja Kementerian Dalam Negeri, 2013). Oleh karena itu Penyuluhan Cuci Tangan Pakai Sabun (CTPS) perlu dilakukan untuk mencegah penyebaran coronavirus khususnya di Kota Mataram.

Berdasarkan latar belakang tersebut maka dilakukanlah kegiatan pengabdian kepada masyarakat dalam bentuk "Penyuluhan Cuci Tangan Pakai Sabun (CTPS) untuk mencegah penyebaran coronavirus". Dalam kegiatan ini dilakukan penyuluhan tentang cara cuci tangan pakai sabun yang baik dan benar untuk menghindari masuknya bakteri ke dalam tubuh yang menempel pada tangan. Hal ini perlu dilakukan mengingat masih kurangnya pengetahuan warga tentang mencuci tangan yang baik dan benar serta mendorong kesadaran masyarakat untuk berperilaku hidup bersih dan sehat

\section{METODE}

Kegiatan pengabdian ini diikuti oleh 20 warga desa geguntur Pelaksanaan kegiatan "Penyuluhan Cuci Tangan Pakai Sabun (CTPS) untuk mencegah penyebaran coronavirus" dilakukan dalam tiga tahap : 
1 Tahap pertama yakni pembagian kuesioner pre test serta pemaparan materi pengabdian tentang Cuci Tangan Pakai Sabun (CPTS). Menurut WHO, terdapat 6 cara melakukan cuci tangan yang benar yaitu: (1) menuangkan handwash pada telapak tangan kemuddian mengusap danmenggosok kedua telapak tangan dengan lembut dengan arah memutar; (2) mengusap dan menggosok kedua punggung tangan secara bergantian; (3) menggosok sela-sela tangan hinggah bersih; (4) membersihkan semua ujung jari secara bergantian dengan posisi saling mengunci; (5) menggosok dan memutar kedua ibu jari secara bergantian; (6) meletakkan ujung jari ke telapak tangan kemuadian menggosok secara perlahan (Sugiarto, Berliana, Yenni, \& Wuni, 2019)

2 Tahap kedua yakni Praktek Cuci Tangan Pakai Sabun (CPTS). Semua peserta mempraktekkan dengan benar dalam pendampingan tim.

3 Tahap ketiga yakni tanya jawab dengan peserta pengabdian serta pemberian kuesioner post test

\section{HASIL DAN PEMBAHASAN}

Kegiatan pengabdian ini diikuti oleh 20 warga desa geguntur dan saat pelaksanaan pengabdian tetap memperhatikan protokol kesehatan d masa pandemi COVID-19 antara lain mengukur suhu badan, wajib menggunakan masker dan jaga jarak. Kegiatan pengabdian dilakukan dalam tiga tahap. Adapun hasil (output) yang didapatkan dari kegiatan ini antara lain :

1. Tahap pertama yakni pembagian kuesioner pre test serta pemaparan materi pengabdian tentang Cuci Tangan Pakai Sabun (CPTS). Hasil dari pre test didapatkan bahwa pengetahuan warga tentang Cuci Tangan Pakai Sabun (CPTS) dalam kategori kurang sebesar $60 \%$ (12 orang).

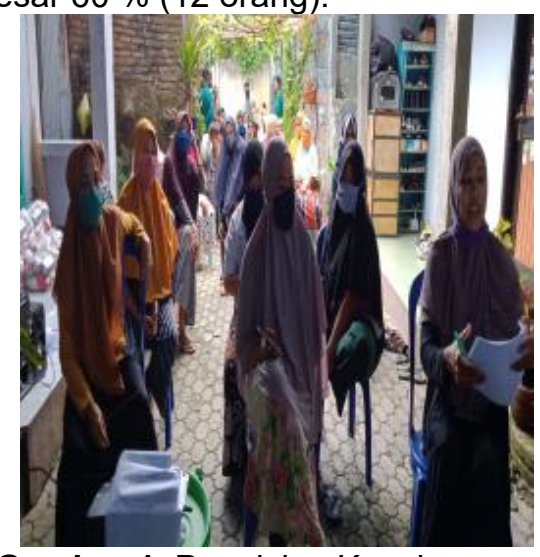

Gambar 1. Pengisian Kuesioner
2. Tahap kedua yakni Praktek Cuci Tangan Pakai Sabun (CPTS). Seluruh peserta melakukan langkah cuci tangan sesuai dengan yang telah dicontohkan oleh tim. Hal ini dapat terlihat pada gambar dibawah ini :

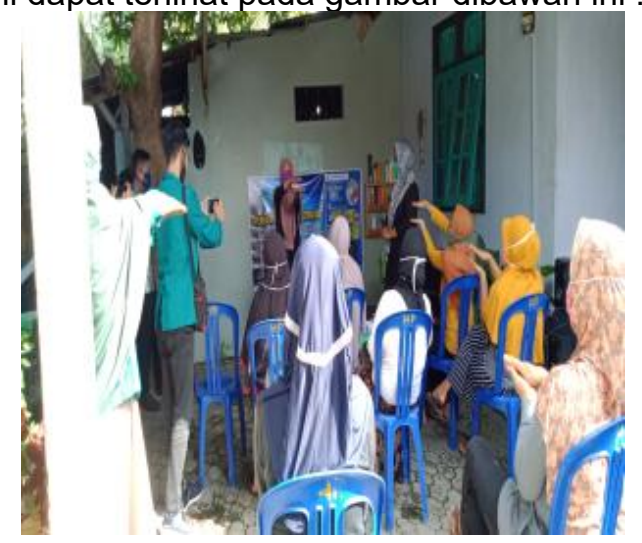

Gambar 2. Praktek Cuci Tangan Pakai Sabun

3. Tahap ketiga yakni tanya jawab dengan peserta pengabdian yakni warga di wilayah kerja Puskesmas Karang Pule khususnya di Lingkungan Geguntur. Para warga sangat antusias melontarkan beberapa pertanyaan terkait tentang Cuci Tangan Pakai Sabun (CPTS). Di sela pertanyaan, warga juga antusias agar kegiatan ini dapat dilakukan kembali dan tidak berhenti sampai disini. Di tahap ini juga dilakukan pembagian kuesioner post test. Hasil dari post test didapatkan bahwa pengetahuan warga tentang Cuci Tangan Pakai Sabun (CPTS) mengalami peningkatan pengetahuan setelah dilakukan penyuluhan yaitu sebagian besar kategori pengetahuan baik sebesar $90 \%$ (18 orang). Pelaksanaan pengabdian masyarakat ini dilakukan di wilayah kerja Puskesmas Karang Pule Kota Mataram salah satunya di Lingkungan Geguntur pada hari Senin, 6 Juli 2020.

\section{SIMPULAN DAN SARAN}

Berdasarkan hasil pengabdian yang dilakukan di wilayah kerja Puskesmas Karang Pule khususnya di Lingkungan Geguntur tentang Cuci Tangan Pakai Sabun (CPTS) dan demontrasi pembuatan cairan disinfektan didapatkan kesimpulan sebagai berikut : Sebagain besar tingkat pengetahuan warga tentang Cuci Tangan Pakai Sabun (CPTS) dalam kategori pengetahuan baik sebesar $90 \%$ ( 18 orang).

\section{UCAPAN TERIMAKASIH}

Ucapan terima kasih kepada pihak yang telah memberikan kontribusi pada pelaksanaan kegiatan ini sehingga dapat berjalan dengan baik sesuai perencanan. Tim 
penulis mengucapkan terima kasih kepada Lembaga Pengabdian Pada Masyarakat (LPPM) Universitas Muhammadiyah Mataram yang telah mendanai kegiatan pengabdian ini sehingga terlaksana dengan baik. Ucapan terima kasih juga kami sampaikan kepada Bidan Koordinator Puskesmas Karang Pule, Kepala Lingkungan, Kader serta warga lingkungan Geguntur yang sudah membantu dan mengikuti kegiatan pengabdian ini sehingga terlaksana dengan baik.

\section{DAFTAR RUJUKAN}

Dewi, D. W., Khotimah, S., \& Liana, D. F. (2016). Pemanfaatan Infusa Lidah Buaya (Aloe vera $L$ ) sebagai Antiseptik Pembersih Tangan terhadap Jumlah Koloni Kuman Jurnal Cerebellum, 2(3), 577-589.

Duerink, D. O., Farida, H., Nagelkerke, N. J. D., Wahyono, H., Keuter, M., Lestari, E. S., Hadi, U., \& Van den Broek, P. J. (2006). Preventing nosocomial infections: improving compliance with standard precautions in an Indonesian teaching hospital. Journal of Hospital Infection, 64(1), $36-43$. https://doi.org/10.1016/j.jhin.2006.03.0 17

Kementrian Kesehatan. (2020). Pedoman COVID REV-4. Pedoman Pencegahan Dan Pengendalian Coronavirus Disease (COVID-19), 1(Revisi ke-4), 1125.

Rajaraman, D., Ks, V., Greenland K, Kumar, C. V, Wp, S., Aunger, R., Biran A, Biran, A., Kumar, R., Greenland, K., Gopalan, B., \& Curtis V. (2014). The Global Public-Private Partnership for Handwashing Implementing effective hygiene promotion: lessons from the process evaluation of an intervention to promote handwashing with soap in rural. Trop Med Int Health India. BMC Public Health Nov, 1914(191), 2014-2016. http://globalhandwashing.org/

Sugiarto, S., Berliana, N., Yenni, M., \& Wuni, C. (2019). Peningkatan Pengetahuan Siswa tentang Cuci Tangan yang Baik dan Benar di SDN 37/l Kecamatan Bajubang. Jurnal Pengabdian Harapan Ibu (JPHI), 1(2), 59. https://doi.org/10.30644/jphi.v1i2.266

Tim Kerja Kementerian Dalam Negeri. (2013). Pedoman Umum Menghadapi Pandemi Covid-19 Bagi Pemerintah Daerah: Pencegahan, Pengendalian, Diagnosis dan Manajemen. Journal of Chemical Information and Modeling, 53(9), 16891699.

https://doi.org/10.1017/CBO97811074
15324.004

Wijaya, J. I. (2013). Formulation of Hand Sanitizer Gel Formulation with Triclosan $1.5 \%$ and $2 \%$ Active Ingredients. University of Surabaya Student Scientific Journal. 2(1), 1-14. 